\title{
GAYA KEPEMIMPINAN SITUASIONAL KEPALA SEKOLAH TERHADAP KINERJA GURU PENDIDIKAN PANCASILA DAN KEWARGANEGAAAN (PPKN) PADA SMA NEGERI SE KABUPATEN BARITO KUALA
}

\author{
Henni Yusda Rahmiyanti \\ Email: henni yr@yahoo.com
}

Guru Pendidikan Pancasila dan Kewarganegaraan SMA Negeri 1 Mandastana Jalan Tabing Rimbah KM 4 Kecamatan Mandastana Kabapaten Barito Kuala

\begin{abstract}
ABSTRAK
Penelitian ini mengunakan pendekatan kuantitatif yang merupakan metode ilmiah untuk memenuhi kaidah-kaidah ilmiah yaitu konkrit empiris, obyektif, terukur, rasional dan sistematis. Studi tentang gaya kepemimpinan situasional kepala sekolah SMA se Kabupaten Barito Kuala ini termasuk jenis penelitian ex-post faktor. Karena mengungkapkan data-data atau peristiwa yang telah berlangsung. Kemudian meruntut ke belakang data-data yang telah ada pada responden tanpa memberikan perlakukan terhadap variabel yang telah diteliti untuk menentukan sebab-sebab atas peristiwa yang diteliti. Jenis penelitian ini dipilih karena dala studi ini bertujuan untuk mengungkapkan seberapa besar pengaruh variabel bebas (gaya kepemimpinan situasional, telling, selling, participating, dan delegating) terhadap variabel terikat (komptensi profesional dan kinerja guru Pendidikan Pancasila dan Kewarganegaraan) yang diukur melalui angket sebagai instrument utamanya. Selanjutnya data yang diperoleh ditabulasi berdasarkan skor yang diperoleh dari setiap variabel dalam bentuk angka-angka dan dianalisis menggunakan statistik untuk menguji hipotesis yang telah dirumuskan

Kata kunci: gaya kepemimpinan situasional kepala sekolah, kinerja guru
\end{abstract}

\begin{abstract}
This study uses a quantitative approach, which is a scientific method to fulfill scientific principles, namely concrete empirical, objective, measurable, rational and systematic. This study of the situational leadership style of high school principals in Barito Kuala Regency is an ex-post factor research. Because it reveals data or events that have taken place. Then trace back the existing data on the respondent without giving treatment to the variables that have been studied to determine the causes of the events under study. This type of research was chosen because in this study it aims to reveal how much influence the independent variables (situational leadership style, telling, selling, participating, and delegating) have on the dependent variable (professional competence and performance of Pancasila and Citizenship Education teachers) which is measured through a questionnaire as the main instrument. Furthermore, the data obtained is tabulated based on the scores obtained from each variable in the form of numbers and analyzed using statistics to test the hypotheses that have been formulated.
\end{abstract}

Key words: principal situational leadership style, teacher performance

\section{PENDAHULUAN}

Di era globalisasi perkembangan ilmu semakin cangggih sehinga menuntut para tenaga pengajar untuk lebih ekstra dalam penerapannya kepada dunia pendidikan. Tidak 
hanya tenaga pengajar saja kemajuan ilmu pengetahuan dan teknologi informasi di era globalisasi juga menuntut profesionalisme kepemimpinan kepala sekolah, kompetensi profesional dan kinerja pendidik. Peningkatan kompetensi dan kinerja pendidik menjadi salah satu tugas pokok kepala sekolah dalam bentuk pembinaan langsung melalui supervisi akademik sekolah. Sallis memperkuat dalam penjelasanya bahwa kompetensi dan motivasi kerja pendidik sangat bergantung pada komitmen pendidik dalam mengembangkan profesinya. Faktor lain adalah efektifitas gaya kepemimpinan kepala sekolah dalam menjalankan fungsi supervisi akademik. Penjelasan ini menunjukan bahwa gaya kepemimpinan situasional menjadi variabel penting. Pentingnya variabel tersebut, sebagaimana ditegaskan Hersey dan Blanchard adalah sebagai kunci pokok yang sangat menentukan efektivitas perilaku seorang pemimpin dalam mempengaruhi bawahan ke arah tercapainya tujuan.

Dengan istilah lain gaya kepemimpinan situasional merupakan variabel yang penting yang mempengaruhi kompetensi dan motivasi kerja pendidik. Hal ini sejalan dengan paradigma gaya kepemimpinan situasional Hersey Blanchard bahwa pemimpin harus mampu menyelaraskan gaya kepemimpinan sesuai dengan situasi tingkat kematangan dan motivasi kerja bawahan.

Bush dan Coleman memperkuat dalam penjelasan yang lebih spesifik bahwa sekolah adalah lembaga pendidikan yang sangat kompleks dan unik. Karena sifatnya yang kompleks dan unik, maka diperlukan skill dalam menganalisis situasi sumber daya manusia yang sangat komplek dan saling terkait. Dari lima hasil studi Bush menunjukan bahwa terdapat beberapa variabel penting yang mempengaruhi efektivitas kepemimpinan pendidikan diantaranya kejelasan visi, strategi yang digunakan untuk mencapai visi, analisis kondisi sumber daya manusia yang diperlukan untuk mencapai visi, tingkat kompetensi sumber daya manusia, kualitas kinerja bawahan dan gaya kepemimpinan yang tepat. Hasil studi Bush memberikan kejelasan terhadap beberapa variabel penting dalam studi ini yang saling mempengaruhi. Diantaranya variabel gaya kepemimpinan situasional, variabel tingkat kompetensi sumber daya manusia dan variabel kualitas kinerja bawahan.

Alexander dalam Mulyasa mengemukakan bahwa dari 10 hasil penelitian pendidikan di negara-negara berkembang menunjukan gaya kepemimpinan situasional berkontribusi besar terhadap beberapa variabel penting yang mempengaruhi kompetensi dan kinerja sumber daya manusia, kualitas kinerja pendidik, prestasi, kualitas kompetensi pendidik, kematangan profesionalisme, disiplin, pengembangan profesi, kemampuan mengelola dan memantaatkan waktu secara efektif dalam proses pembelajaran yang bermutu, semuanya menjadi tanggungjawab pimpinan sekolah, pusat pengembangan kompetensi tenaga pendidik, asosiasi profesi, pengawas sekolah dan atau lembaga sejenis lainya.

Dari penjelasan di atas, dapat dipertegas bahwa terdapat beberapa variabel penting yang saling mempengaruhi dimana variabel gaya kepemimpinan situasional menjadi variabel utama yang memiliki pengaruh timbal balik terhadap kompetensi sumber daya manusia, kinerja sumber daya manusia, kualitas kinerja, prestasi, kualitas kompetensi, kematangan profesionalisme, disiplin, pengembangan profesi, kemampuan mengelola dan memantaatkan waktu secara efektif dalam proses pembelajaran yang bermutu.

\section{KAJIAN TEORI \\ Konsep pengaruh dan gaya kepemimpinan situasional}


Pengaruh adalah daya yang ada atau timbul dari sesuatu (orang atau benda) yang membentuk watak kepercayaan dan perbuatan seseorang. Poerwardaminta mendefiniskan pengaruh adalah daya yang ada atau timbul dari sesuatu, baik orang maupun benda dan sebagainya yang berkuasa atau yang berkekuatan dan berpengaruh terhadap orang lain. Sedangkan gaya adalah sikap atau perilaku yang konsisten. Adapun kepemimpinan adalah kemampuan mempengaruhi suatu kelompok kearah pencapaian tujuan. Searah dengan definisi tersebut Handoko, Soetopa dan Soemanto mendefinisikan kepemimpinan adalah kemampuan dan kesiapan seorang pemimpin dalam membimbing, memengaruhi dan menggerakkan bawahan dalam mencapai tujuan bersama.

Hasil studi Hersey dan Blanchard dalam Makawimbang yang terbesar adalah model kepemimpinan situasional yang dikembangkan ke dalam 4 kuadran sebagaimana dideskripsikan dalam diagram sebagai berikut:

\section{Tabel 1}

\section{Diagram Model Kepemimpinan Situasional Hersey dan Blanchard.}

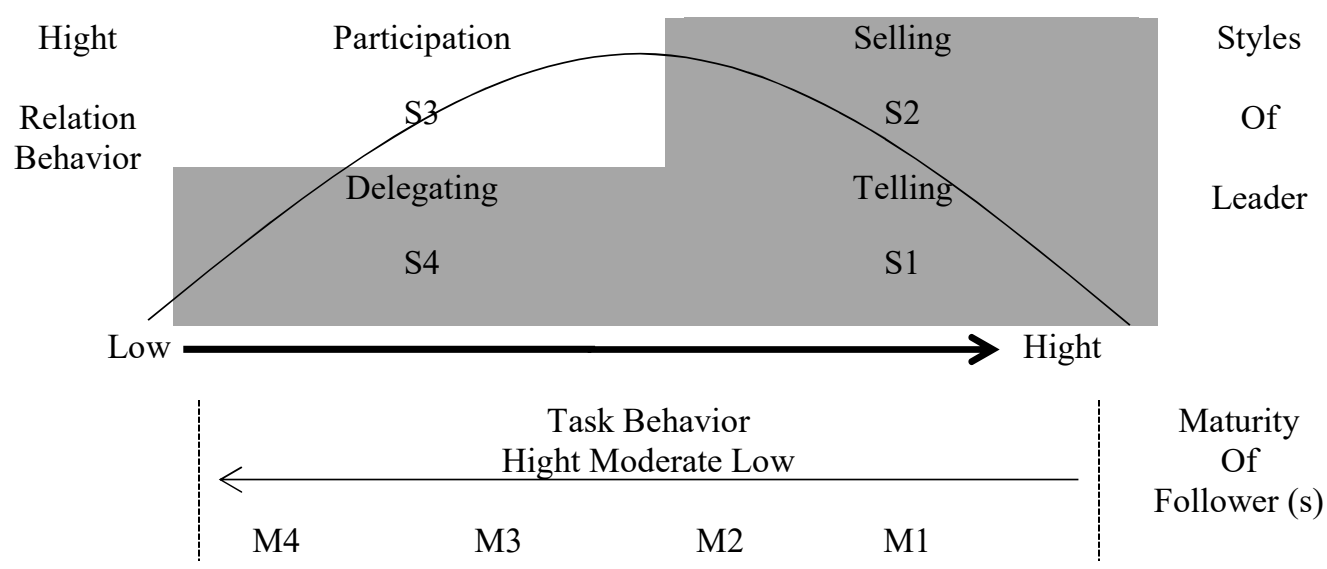

Berdasarkan situasi dan tingkat kematangan atau kesiapan bawahan yang dihubungkan dengan perilaku pemimpin yang efektif dalam mempengaruhi dan menggerakkan bawahan, Hersey dan Blanchard membagi model kepemimpinan situasional yang efektif ke dalam empat kuadran sebagaimana dijelaskan dalam diagram di atas. Selanjutnya tentang empat model kuadran yang mendasari gaya kepemimpinan situasional dalam teori Hersey dan Blanchard dikembangkan Mitchell L.

\section{METODE PENELITIAN}

Studi ini mengunakan pendekatan kuantitatif yang merupakan metode ilmiah untuk memenuhi kaidah-kaidah ilmiah yaitu konkrit empiris, obyektif, terukur, rasional dan sistematis berdasarkan kerangka filsafat positivism yang memandang realitas atau gejala ini dapat diklasifikasikan, relatif tetap, konkrit, teramati, terukur dan hubungan gejala kausalitas.

Studi tentang pengaruh gaya kepemimpinan situasional kepala sekolah SMA se Kabupaten Barito Kuala ini termasuk jenis penelitian ex-post factor. Karena mengungkapkan data-data atau peristiwa yang telah berlangsung. Kemudian meruntut ke belakang data-data yang telah ada pada responden tanpa memberikan perlakukan terhadap variabel yang telah diteliti untuk menentukan sebab-sebab atas peristiwa yang diteliti. Jenis penelitian ini dipilih karena dala studi ini bertujuan untuk mengungkapkan seberapa besar pengaruh variabel bebas (gaya kepemimpinan situasional, telling, selling, participating, dan delegating) terhadap variabel terikat (komptensi profesional dan 
kinerja guru Pendidikan Pancasila dan Kewarganegaraan) yang diukur melalui angket sebagai instrument utamanya. Selanjutnya data yang diperoleh ditabulasi berdasarkan skor yang diperoleh dari setiap variabel dalam bentuk angka-angka dan dianalisis menggunakan statistik untuk menguji hipotesis yang telah dirumuskan.

\section{PENELITIAN DAN HASIL PEMBAHASAN \\ Penelitian}

Masalah dalam penelitian ini adalah apakah gaya kepemimpinan situasional telling (X1), selling (X2), participating (X3) dan delegating (X4) dalam supervisi akademik kepala sekolah memberikan pengaruh terhadap kompetensi professional (Y1) dan kinerja guru Pendidikan Pancasila dan Kewarganegaraan (Y2) se Kabupaten Barito Kuala? Untuk menjawab masalah penelitian ini, peneliti menggunakan analisis korelasi kanonikal. Berikut adalah beberapa hasil kuesioner dari masing-masing variabel sebelum dilakukan ujikorelasi kanonikal.

1. Hasil Kinerja Guru Pendidikan Pancasila dan Kewarganegaraan.

Dalam bagian ini disajikan data hasil kuisioner kinerja guru Pendidikan Pancasila dan Kewarganegaraan yang telah dibagikan pada tanggal 26 Januari 2020 kepada 30 responden yang terdiri atas kepala sekolah dan guru Pendidikan Pancasila dan Kewarganegaraan dari 10 SMA se Kabupaten Barito Kuala didiskripsikan pada tabel berikut:

\section{Tabel 2}

\section{Hasil Kinerja Guru Pendidikan Pancasila dan Kewarganegaraan}

Kinerja guru

\begin{tabular}{|l|r|}
\hline P Valid & 90 \\
Missing & 0 \\
Mean & 128.18 \\
Median & 126.00 \\
Mode & 126 \\
Std. Deviation & 9.174 \\
Minimum & 111 \\
Maximum & 152 \\
Sum & 11536 \\
\hline
\end{tabular}

Berdasarkan tabel tersebut diketahui bahwa jumlah responden 90; nilai maksimum sebesar 152.00 nilai minimum sebesar 111.00, rata-rata sebesar 128,18 serta standar deviasi sebesar 9.174. Hasil kuesioner kinerja guru, didiskripsikan pada grafik berikut: 


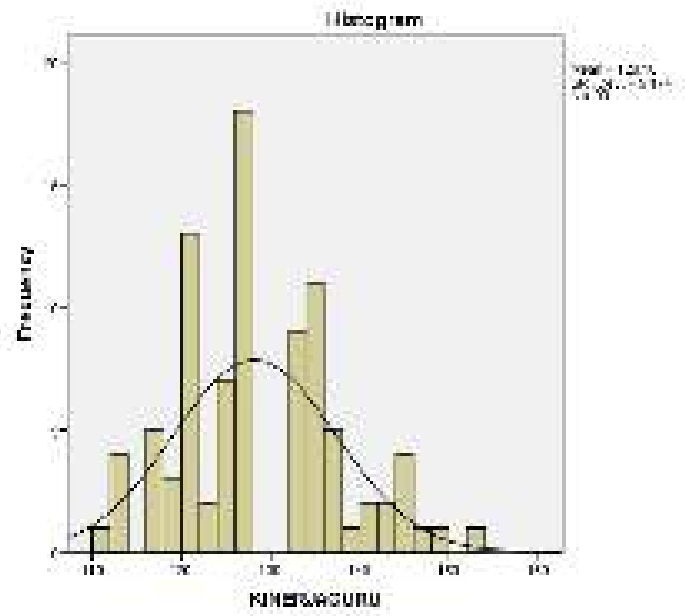

Grafik

Hasil Kuisioner Kinerja Guru Pendidikan Pancasila dan Kewarganegaraan.

2. Uji asumsi untuk analisis korelasi kanonikal

Sebelum pengolahan data dilakukan dengan kononikal, terlebih dahulu dilakukan uji asumsi atas persyaratan-persyaratan yang harus dipenuhi yaitu uji normalitas,uji multikolinear dan uji linearitas dari masing-masing variabel.

Uji normalitas untuk mengetahui suatu model korelasi kanonikal, variabel dependen, variabel independen atau keduanya berdistribusi normal atau tidak. Model korelasi kanonikal yang baik adalah berdistribusi normal atau mendekati normal. Dalam hal ini analisis Kolmogorov-Smirnov merupakan suatu pengujian normalitas secara univariate untuk menguji keselarasan data dari masing-masing variabel penelitian, dimana suatu sampel dikatakan berdistribusi normal atau tidak. Data disajikan dalam tabel sebagai berikut:

Tabel 3

Hasil uji Kolmogorov- Smirnov

One-Sample Kolmogorov-Smirnov Test

\begin{tabular}{|ll|r|r|r|r|r|r|}
\hline & & & & \multicolumn{1}{c|}{ PARTI } & DELEGA & PROFESIO & \\
& & TELLING & SELLING & CIPATING & \multicolumn{1}{c|}{ TING } & \multicolumn{1}{c|}{ NAL } & KINERJA \\
\hline $\mathrm{N}$ & 90 & 90 & 90 & 90 & 90 & 90 \\
Normal & Mean & 34.28 & 28.94 & 32.02 & 34.63 & 124.50 & 137.54 \\
Parameters & & & & & \\
& Std. & & & & & & \\
& Deviatio & 3.696 & 2.766 & 2.151 & 2.286 & 7.141 & 7.867 \\
Most EXtreme & Absolute & .144 & .123 & .182 & .181 & .127 & .112 \\
Differences & Positive & .121 & .123 & .182 & .181 & .117 & .110 \\
& Negative & -.144 & -.082 & -.107 & -.126 & -.127 & -.112 \\
Kolmogorov-Smirnov Z & 1.367 & 1.162 & 1.726 & 1.714 & 1.209 & 1.058 \\
Asymp. Sig. (2-tailed) & .048 & .134 & .005 & .006 & .107 & .213 \\
\hline
\end{tabular}

Jika VIF $<10$ atau Tolerance $>0,1$ maka H0 diterima, tidak ada multikolinearitas. Hasil yang tampak dari uji multikolinieritas adalah seperti di bawah ini:

Tabel 4

Coefficients Collinearity Statistics 


\begin{tabular}{|c|c|c|}
\hline \multirow[t]{2}{*}{ Model } & \multicolumn{2}{|c|}{ Collinearity Statistics } \\
\hline & Tolerance & VIF \\
\hline $1 \mathrm{X} 1$ & .949 & 1.054 \\
\hline X2 & .964 & 1.038 \\
\hline X3 & .929 & 1.076 \\
\hline X4 & .967 & 1.034 \\
\hline
\end{tabular}

a. Dependent Variable: Y1 dan Y2

Ternyata nilai VIF mendekati 1 untuk semua variabel bebas $(1.054,1.038$, 1.076, dan 1.034). Demikian pula, nilai tolerance mendekati 1 untuk semua variabel bebas. Dengan demikian, dapat ditegaskan bahwa dalam regresi antara variabel bebas telling (X1), selling (X2), participating (X3) dan delegating (X4) terhadap kompetensi professional dan kinerja kinerja guru pendidikan Pancasila dan Kewarganegaraan (y) tidak terjadi multikolinieritas antar variabel bebas.

a. Uji linieritas

Pengujian linearitas telah dilakukan satu persatu pasangan variabel secara bergantian antara variabel dependen dengan independen dengan menggunakan korelasi. Berdasarkan hasil perhitungan diasumsikan regresinya linear, hal ini telah dilakukan agar dapat menggunakan perhitungan korelasi kanonikal.

Uji linieritas juga telah dilakukan dengan menggunakan ujiAnova untuk mengetahui apakah hubungan antar variabel tersebut membentuk garis lurus atau tidak. Jika nilai siknifikan uji Anova lebih besar dari 0.05, maka nilai tersebut memenuhi asumsi linieritas atau membentuk garis lurus. Berikut disajikan hasil uji linieritas pada tabel berikut:

Tabel 5

Hasil Uji Linieritas

\begin{tabular}{|c|c|c|c|c|c|}
\hline \multicolumn{6}{|c|}{ ANOVA Table } \\
\hline & $\begin{array}{c}\text { Sum of } \\
\text { Squares }\end{array}$ & df & $\begin{array}{c}\text { Mean } \\
\text { Square }\end{array}$ & $\mathbf{F}$ & Sig. \\
\hline Between (Combined) & 1048.418 & 10 & 104.842 & 2.373 & .016 \\
\hline Groups Linearity & 1.219 & 1 & 1.219 & .028 & .868 \\
\hline $\begin{array}{l}\text { Deviation from } \\
\text { Linearity }\end{array}$ & 1047.199 & 9 & 116.355 & 2.634 & .010 \\
\hline Within Groups & 3490.082 & 79 & 44.178 & & \\
\hline Total & 4538.500 & 89 & & & \\
\hline Between (Combined) & 888.580 & 10 & 88.858 & 1.520 & .148 \\
\hline Groups Linearity & .089 & 1 & .089 & .002 & .969 \\
\hline $\begin{array}{l}\text { Deviation from } \\
\text { Linearity }\end{array}$ & 888.491 & 9 & 98.721 & 1.688 & .106 \\
\hline Within Groups & 4619.742 & 79 & 58.478 & & \\
\hline Total & 5508.322 & 89 & & & \\
\hline
\end{tabular}

Hasil analisis menunjukkan bahwa harga $\mathrm{F}$ sebesar 2.634 dan 1.688 dengan signifikansi 0.010 dan 0,106. Interpretasi hasil analisis dilakukan dengan: 
1) Menyusun hipotesis: H0: Model regresi linier H1: Model regresi tidak linier.

2) Menetapkan taraf signifikansi (misalnya $a=, 05$ )

3) Membandingkan signifikansi yang telah ditetapkan dengan signifikansi yang diperoleh dari analsisis (Sig.) Bila a Sig., maka HO diterima, berarti regresi.

Ternyata hasil analisis menunjukkan bahwa sig. $(2.634$ dan 1.688$)>a(0,05)$, berarti model regresi linier.

Berdasarkan hasil analisis di atas, maka diperoleh hasil studi sebagai berikut:

1. Hasil analisis korelasi kanonik untuk faktor-faktor yang mempengaruhi kompetensi profesional guru Pendidikan Pancasila dan Kewarganegaraan (Y1) dan kinerja guru Pendidikan Pancasila dan Kewarganegaraan (Y2) adalah gaya participating (X3) terhadap (Y2) sebesar 0.61648, dan (Y1) sebesar 0. 60011; gaya delegating (X4) terhadap (Y1)sebesar -0.82885 dan (Y2) sebesar 0. 32603; gaya telling (X1) terhadap (Y1) sebesar -0.10105 dan (Y2) sebesar 0.20842; dan gaya selling (X2) terhadap (Y1) sebesar -0. 09074; dan (Y2) 0.48314.

2. Berdasarkan analisis korelasi kanonik, hubungan antara indikator pada variabel kompetensi profesional dan kinerja guru Pendidikan Pancasila dan Kewarganegaraan dengan variabel gaya kepemimpinan situasional participating (X3) telah menunjukan korelasi searah. Hal ini menunjukan semakin tinggi gaya kepemimpinan participating kepala sekolah akan semakin tinggi pula peningkatan kinerja guru Pendidikan Pancasila dan Kewarganegaraan dan sebaliknya.

3. Dua variabel dependen dan variabel independen secara kelompok memiliki hubungan signifikan.Atau terdapat hubungan antara gaya kepemimpinan situasional telling (X1), selling (X2), participating (X3) dan delegating (X4) kepala sekolah terhadap kompetensi profesioanal (Y1) dan kinerja guru Pendidikan Pancasila dan Kewarganegaraan (Y2) di SMA se Kabupaten Barito Kuala.

4. Pada variabel telling (X1) memberikan pengaruh tidak langsung sebesar -0. 10105 terhadap kompetensi profesional guru Pendidikan Pancasila dan Kewarganegaraan (Y1) dan pengaruh langsung terhadap kinerja guru Pendidikan Pancasila dan Kewarganegaraan (Y2) sebesar 0.20842.

5. Pada variabel selling (X2) memberikan pengaruh tidak langsung sebesar -0. 09074 terhadap kompetensi professional guru (Y1), tetapi memberikan pengaruh langsung terhadap kinerja guru Pendidikan Pancasila dan Kewarganegaraan (Y2) sebesar 0.48314.

6. Pada Variabel participating (X3) memberikan pengaruh langsung terhadap kompetensi profesional guru Pendidikan Pancasila dan Kewarganegaraan (Y1), sebesar 0.61648 dan kinerja guru Pendidikan Pancasila dan Kewarganegaraan (Y2) sebesar 0.60011. Artinya semakin baik gaya kepemimpinan situasional kepala sekolah (X3), semakin baik pula kinerja guru (Y2) dan kompetensi profesional guru (Y1).

7. Pada variabel delegating (X4) memberikan pengaruh tindak langsung sebesar 0.82885 terhadap kompetensi profesional guru Pendidikan Pancasila dan Kewarganegaraan (Y1), tetapi memberikan pengaruh langsung terhadap kinerja guru Pendidikan Pancasila dan Kewarganegaraan (Y2) sebesar 0. 32603. 
8. Gaya kepemimpinan situasional model participating (X3) kepala sekolah sangat dominan berpengaruh terhadap kinerja guru Pendidikan Pancasila dan Kewarganegaraan (Y2).

Berdasarkan pengujian analisis korelasi kanonik dapat ditegaskan bahwa terdapat pengaruh signifikan antara gaya kepemimpinan situasional telling, selling, participating, dan delegating kepala sekolah terhadap kompetensi profesional guru dan kinerja guru Pendidikan Pancasila dan Kewarganegaraan di SMA se Kabupaten Barito Kuala. Dari hasil studi ini diperoleh rumusan empat premis penting sebagai berikut:

1. Gaya kepemimpinan telling (S1) dalam supervisi akademik kepala sekolah lebih tepat diterapkan bagi kelompok guru Pendidikan Pancasila dan Kewarganegaraan yang tingkat kompetensi profesional dan motivasi kerja rendah. Gaya kepemimpinan telling ini dapat digunakan sebagai petunjuk dan landasan bagi para kepala sekolah dalam melakukan bimbingan dan pengarahan bagi kelompok guru yang tingkat kompetensi profesional dan motivasi kerja atau dalam melaksanakan tugas sebagai pendidik masih rendah (R1). Premis pertama merupakan hasil pengembangan dari teori Hersey, Blanchard dan Mitchell L. Springer pada model kuadran I.

2. Gaya kepemimpinan selling (S2) tepat diterapkan bagi kelompok guru Pendidikan Pancasila dan Kewarganegaraan yang tingkat kompetensi profesional dan motivasi kinerja cukup. Tetapi tidak tepat diterapkan pada kelompok guru Pendidikan Pancasila dan Kewarganegaraan yang tingkat kompetensi profesional rendah. Gaya kepemimpinan selling ini dapat digunakan sebagai petunjuk dan landasan bagi para kepala sekolah dalam melakukan bimbingan dan pengarahan bagi kelompok guru yang tingkat kompetensi profesional kurang tetapi memiliki motivasi kerja atau dalam melaksanakan tugas sebagai pendidik cukup (R2). Permis kedua merupakan hasil pengembangan dari teori Hersey, Blanchard dan Mitchell L. Springer pada model kuadran II.

3. Gaya kepemimpinan participating (S3) tepat diterapkan pada kelompok guru Pendidikan Pancasila dan Kewarganegaraan yang tingkat kompetensi profesional kurang tetapi memiliki motivasi kerja kuat. Gaya kepemimpinan selling ini dapat digunakan sebagai petunjuk dan landasan bagi para kepala sekolah dalam melakukan bimbingan dan pengarahan bagi kelompok guru yang tingkat kompetensi profesional kurang tetapi memiliki motivasi kerja atau dalam melaksanakan tugas sebagai pendidik kuat (R3). Premis ketiga merupakan hasil pengembangan dari teori Hersey, Blanchard dan Mitchell L. Springer pada model kuadran III.

4. Gaya kepemimpinan delegating tidak tepat diterapkan pada kelompok guru Pendidikan Pancasila dan Kewarganegaraan yang tingkat kompetensi profesional rendah, atau cukup. Tetapi lebih tepat diterapkan pada kelompok guru Pendidikan Pancasila dan Kewarganegaraan yang tingkat kompetensi profesional dan motivasi kerja tinggi. Gaya kepemimpinan delegating ini dapat digunakan sebagai petunjuk dan landasan bagi para kepala sekolah dalam melakukan bimbingan dan pengarahan bagi kelompok guru yang tingkat kompetensi profesional tinggi dan memiliki motivasi kerja atau dalam melaksanakan tugas sebagai pendidik tinggi (R4). Premis keempat merupakan hasil pengembangan dari teori Hersey, Blanchard dan Mitchell L. Springer pada model kuadran IV. 
Secara teoritis, empat premis gaya kepemimpinan situasional kepala sekolah di atas merupakan pengembangan dari teori kepemimpinan situasional Hersey, Blanchard dan Mitchell L. Springer yang masih sangat umum dan luas, ke dalam gaya kepemimpinan situasional yang lebih praktis, apilkatif dan spesifik pada gaya kepemimpinan situasional kepala sekolah untuk memperkaya teori kepemimpinan situasional dan dapat digunakan sebagai rujukan dan landasan bagi kepala sekolah dalam meningkatkan kompetensi profesional guru dan kinerja guru berdasarkan tingkat kematangan kompetensi profesional dan motivasi kerja guru yang lebih aplikatif dan operasional.

\section{KESIMPULAN}

Berdasarkan temuan tersebut ditegaskan bahwa secara simultan, terdapat pengaruh signifikan antara gaya kepemimpinan situasional kepala sekolah telling, selling, participating dan delegating terhadap kompetensi professional dan motivasi kerja guru Pendidikan Pancasila dan Kewarganegaraan.

Gaya kepemimpinan telling (S1) dalam supervisi akademik kepala sekolah lebih tepat diterapkan bagi kelompok guru Pendidikan Pancasila dan Kewarganegaraan yang tingkat kompetensi profesional dan motivasi kerja rendah. Gaya kepemimpinan telling ini dapat digunakan sebagai petunjuk dan landasan bagi para kepala sekolah dalam melakukan bimbingan dan pengarahan bagi kelompok guru yang tingkat kompetensi profesional dan motivasi kerja atau dalam melaksanakan tugas sebagai pendidik masih rendah $(\mathrm{R} 1)$.

Gaya kepemimpinan selling (S2) tepat diterapkan bagi kelompok Pendidikan Pancasila dan Kewarganegaraan yang tingkat kompetensi profesional dan motivasi kinerja cukup. Tetapi tidak tepat diterapkan pada kelompok guru Pendidikan Pancasila dan Kewarganegaraan yang tingkat kompetensi profesional rendah. Gaya kepemimpinan selling ini dapat digunakan sebagai petunjuk dan landasan bagi para kepala sekolah dalam melakukan bimbingan dan pengarahan bagi kelompok guru yang tingkat kompetensi profesional kurang tetapi memiliki motivasi kerja atau dalam melaksanakan tugas sebagai pendidik cukup (R2).

Gaya kepemimpinan participating (S3) tepat diterapkan pada kelompok guru Pendidikan Pancasila dan Kewarganegaraan yang tingkat kompetensi profesional kurang tetapi memiliki motivasi kerja kuat. Gaya kepemimpinan selling ini dapat digunakan sebagai petunjuk dan landasan bagi para kepala sekolah dalam melakukan bimbingan dan pengarahan bagi kelompok guru yang tingkat kompetensi professional kurang tetapi memiliki motivasi kerja atau dalam melaksanakan tugas sebagai pendidik kuat (R3).

Gaya kepemimpinan delegating tidak tepat diterapkan pada kelompok guru Pendidikan Pancasila dan Kewaganegaraan yang tingkat kompetensi profesional rendah, atau cukup. Tetapi lebih tepat diterapkan pada kelompok guru Pendidikan Pancasila dan Kewarganegaraan yang tingkat kompetensi profesional dan motivasi kerja tinggi. Gaya kepemimpinan delegating ini dapat digunakan sebagai petunjuk dan landasan bagi para kepala sekolah dalam melakukan bimbingan dan pengarahan bagi kelompok guru yang tingkat kompetensi profesional tinggi dan memiliki motivasi kerja atau dalam melaksanakan tugas sebagai pendidik tinggi (R4).

\section{DAFTAR PUSTAKA}

Arimbi, Vela Miarri Nurma, (2012). Pengaruh Kepemimpinan Kepala Sekolah Terhadap Kinerja Guru SMK Negeri Di Temanggung. Yogyakarta: UNY Press. 
Barizi, Ahmad \& Muhammad Idris (2010). Menjadi Guru Unggul. Jogjakarta: Ar-Ruzz Media, 2010.

Basri, (2014). Kepemimpinan Pendidikan di Sekolah. Bandung: Pustaka Setia.

Bush, Tony dan Marianne Coleman (2010). Manajemen Strategis dan Kepemimpinan Pendidikan. Yogyakarta: IrciShod

Coe, Robert, (2002). What effect size is and why it is important, Paper presented at the Annual Conference of the British Educational Research Association, University of Exeter, England, 12-14 September 2002 School of Education, University of Durham: Durham Unversity Press.

Engvik, Gunnar, (2017). “The Importance of School Leaders' Engagement in Socialising Newly Qualified Teachers into the Teaching profession" The international journal of Leadership and Education Theory and Practice Vol, 20.

Fielders. (2004). The Situational Leadership dalam Trianto Safaria. Kepemimpinan Yogyakarta: Garaha Ilmu.

Ngalimun, (2014). Strategi dan Model Pembelajaran. Yogyakarta: Aswaja Pressindo.

Priansa, Donni Juni dan Rismi Somad (2014). Manajemen Supervisi dan Kepemimpinan Kepala Sekolah. Bandung: Alfabeta.

Sallis, Edward. Total Quality, (2011). Management in Decuation,. Yogyakarta: Ircisod

Spencer, Peter M dan Signe M. Spencer. (1993). Competence at Work Models for Superior Performance. New York: Jhon Wiley \& Sons. Inc.

Springer, Mitchell L. (2004). The Art and Sciene of Program Management A Comprehensive Overview of The Discipline. Mumbai: Jaico

Wahab, Abdul Aziz, (2012). Anatomi Organisasi dan Kepemimpinan Pendidikan Telaah terhadap Organisasi dan Pengelolaan Organisasi Pendidikan. Bandung: Alfabeta. 